\title{
Storage Related Haematological and Biochemical Changes of CPDA-1 Whole Blood in a Resource Limited Setting
}

\author{
Teddy C Adias ${ }^{1}$, Beatrice Moore-Igwe ${ }^{2}$ and Zaccheaus A Jeremiah ${ }^{3 *}$ \\ ${ }^{1}$ College of Health, Health Technology, Otuogidi-Ogbia, Nigeria \\ ${ }^{2}$ Department of Medical Laboratory Servives, Braithwaite Memorial and Specialist Hospital, Port Harcourt, Nigeria
}

${ }^{3}$ Haematology and Blood Transfusion Unit, Department of Medical Laboratory Science, College of Health Sciences, Niger Delta University, Wilberforce Island, Nigeria

\begin{abstract}
Majority of the blood banks in Nigeria still practice whole blood banking. The changes associated with the storage of blood in our blood banks have not been reported. This study was aimed at bridging this gap. Blood $(450 \mathrm{ml})$ was drawn from ten healthy volunteer donors into CPDA-1 anticoagulant and placed on the quarantine shelf of the blood bank refrigerator maintained at $2-8^{\circ} \mathrm{C}$. Blood bags were screened for HCV, HBsAg, Syphilis and HIV $1 \& 2$ and were confirmed negative. Samples were collected at 1, 7, 14, 21 and 28 days and tested for hematological and biochemical using the PE-600 fully auto Haematology analyzer (China) for hematological parameters, Excite -40 ESR analyzer and Prestige 24i automated clinical analyzer for biochemical parameters. Comparison of day 1 versus day 7 revealed that the granulocytes were drastically reduced from $1.93 \times 10^{9} / \mathrm{L}$ on day 1 to $0.33 \times 10^{9} / \mathrm{L}$ on day $7(F=48.79, p=0.000$, ESR values increased from $2.90 \mathrm{~mm} / \mathrm{hr}$ on day 1 to $6.60 \mathrm{~mm} / \mathrm{hr}$ on day $7(\mathrm{~F}=7.45, \mathrm{p}=0.013$. For biochemical parameters, there was a significant decrease in $\mathrm{Na}$ value from $137.38 \mathrm{mEq} / \mathrm{L}$ on day 1 to $135 \mathrm{mEq} / \mathrm{L}$ on day $7(\mathrm{~F}=43.66, \mathrm{p}=0.000)$. Analysis of variance (ANOVA) showed that at the end of 28 days, there was significant changes in WBC, differential and absolute leucocytes, MPV, PDW, and ESR, albumin and potassium were significantly affected among the biochemical parameters. No significant changes were observed in $\mathrm{Hb}, \mathrm{PCV}$ and other hematological parameters throughout the study. Rapid degeneration of leukocytes could lead to immunodulation related to blood transfusion. Whole blood should be leukodepleted before storage if it must be used beyond one week.
\end{abstract}

Keywords: Whole blood; Haematological; Biochemical; Storage

\section{Introduction}

Preservation and long term storage of Red Blood Cells (RBCs) is needed to ensure a readily available, safe blood supply for transfusion medicine. Blood collection and storage systems licensed by the Food and Drug Administration allow red cells to be stored up to 42 days, while the median duration of storage of transfused red cell units in the United State is 15 days [1]. Some studies have suggested that the risk of complications after transfusion increases when transfused blood has been stored for long periods [1]. During storage, in fact, preserved blood cells undergo progressive structural and functional changes that may reduce red cell function and viability after transfusion [1].

Storage has a negative effect on RBC oxygen delivery [2] and emerging evidence suggests that allogenic RBC infusion may actually harm some recipients. Considerable evidence suggests that transfusion increases the risk of serious complications and death in critically ill patients, especially in patients who are undergoing cardiac surgery. Current research indicated that the $\mathrm{RBC}$ hypothermic storage lesion is responsible for the association of blood transfusion with an increased length of stay in the hospital, impaired tissue oxygen use, pro-inflammatory and immunomodulatory effects, increased infections, multiple organ system failure, and ultimately increased morbidity and mortality [3]. Clinical implications, collectively known as the RBC storage medium lesion, is in part related to bioreactive substances released by leucocytes in the storage medium, such as histamine, lipids, and cytokines, which may exert direct effect on metabolic and physical changes associated with the senescence, such as membrane reticulation, decrease in cell size, increase of cell density, alteration of cytoskeleton, enzymatic desilylation, and phosphatidylserine exposure, RBCs lose potassium 2,3-diphosphoglycerate (2, 3-DPG), Adenosine Triphosphate (ATP) stores, lipids and membrane, while becoming more rigid and demonstrating reduced oxygen off-loading [4]. Moreover, stored units become more acidotic and the suspending fluid has higher concentrations of free hemoglobin and biologically active lipids, and contains greater quantities of negatively charged microvesicles with proinflammatory and procoagulant activity [4].

Platelets circulate longer when stored at room temperature and are more activated and able to form clot more effectively when stored at $4^{\circ} \mathrm{C}$ [5]. White cells lose their phagocytic property within 4-6 hrs of collection and become non-functional after $24 \mathrm{hrs}$ of storage [6] It is important to remember they do not lose their antigenic property and are capable of sensitizing the recipient to produce non-haemolytic febrile transfusion reactions. Few lymphocytes may remain viable even after 3 weeks of storage. There is limited evidence to suggest that some biochemical analytes (such as cholesterol) may be stable in whole blood for several days at ambient temperature [7-9]. The only important electrolyte change in stored blood is that of potassium. During blood storage there is a slow but constant leakage of $\mathrm{K}$ from cells into the surrounding plasma. In severe kidney disease even small amount of $\mathrm{K}$ fluctuations can be dangerous and relatively fresh or washed red cells are indicated. Due to a higher K content of stored blood, blood $<5$ days old is recommended by Ono et al. [7] for neonatal exchange and top-up transfusion.

*Corresponding author: Dr. Zaccheaus Awortu Jeremiah, Department of Medical Laboratory Science, College of Health Sciences, Niger Delta University, Wilberforce Island, Nigeria, Tel: +234 803404 5636; E-mail: za.jeremiah@mail.ndu.edu.ng/ zacjerry@yahoo.com

Received June 20, 2012; Accepted July 20, 2012; Published July 23, 2012

Citation: Adias TC, Moore-Igwe B, Jeremiah ZA (2012) Storage Related Haematological and Biochemical Changes of CPDA-1 Whole Blood in a Resource Limited Setting. J Blood Disorders Transf 3:124. doi:10.4172/2155-9864.1000124

Copyright: $\odot 2012$ Adias TC, et al. This is an open-access article distributed under the terms of the Creative Commons Attribution License, which permits unrestricted use, distribution, and reproduction in any medium, provided the original author and source are credited. 
This work examines changes that occur in some hematological and biochemical parameters of whole blood stored in blood bank in a resource limited setting with a view to assessing the possible duration of storage for maximal utility in blood transfusion.

\section{Materials and Methods}

\section{Study area and subjects}

This study was conducted in Braithwaite Memorial Specialist Hospital (BMSH), located in the city of Port Harcourt, Rivers State, Nigeria. The geographical location of Rivers State is Latitude $4^{\circ} 31^{\prime}$ $5^{\circ} 31^{\prime}$ and longititude $6^{\circ} 30^{\prime}-7^{\circ} 21^{\prime}$. BMSH is a 346 bed specialist hospital owned by Rivers State Government with a standard blood bank laboratory. The study spanned between 21 August and 18 September 2009. Blood $(450 \mathrm{ml})$ was drawn from ten healthy volunteer donors into Citrate Phosphate Dextrose Adenine (CPDA-1) anticoagulant and placed on the quarantine shelf of the blood bank refrigerator. The donors were 10 in number; they had their ages ranging from 23 to 28 years (mean age $25.2 \mathrm{yrs}$ ) with corresponding blood groups of $1 \mathrm{~A}-, 1 \mathrm{~A}$, $2 \mathrm{~B}^{+}, 5 \mathrm{O}^{+}$and $1 \mathrm{O}^{-}$. The donors were all male and tested negative for: HCV, HbsAg, Syphilis and HIV 1 \& 2.

\section{Blood collection and storage}

Blood bag: Blood bag of $450 \mathrm{ml} \pm 10 \%$ (Agarry) which contains CPDA-1 was used. Citrate phosphate dextrose adenine solution was developed in 1968 and shown to permit whole-blood storage for 5 weeks [10]. The citrate prevents coagulation by binding or chelating to calcium, phosphate acts as a buffer hence, maintains the $\mathrm{pH}$ of the blood. Dextrose serves as substrate for the blood cells, while adenine maintains high ATP level in the RBC. Most blood collection bags (adult) contain $63 \mathrm{ml}$ CPDA anticoagulant which is sufficient to anticoagulate and ensure the viability of blood cells in $450 \mathrm{ml} \pm 10 \%$ blood for up to 28-35 days when the blood is stored at $2-8^{\circ} \mathrm{C}[11]$.
Collection procedure Phlebotomy: Collection of blood was performed as described by Monica [11]. Blood was collected from each of the donors with care and adequate safety precautions to avoid contamination and infection from blood transmissible pathogens. Protective gloves were worn during collection and syringes were sterile and dry and blood collecting materials were discarded safely to avoid injury from needles and lancets. Blood bags were carefully stored in a quarantine shelf in the blood bank, with temperature ranging from $2-6^{\circ} \mathrm{C}$. Foster refrigerator was the blood bank used.

\section{Procedures}

Haematological parameters: These parameters were measured using autoanalyser. The PE-600, fully auto Hematology Analyzer (China) was used, while Excite-40 ESR analyser was used to analyse ESR (Vital Diagnostics, USA). PE-600 works on the principle of electrical resistance for counting, hemoglobincyanide method and SFT method for hemoglobin. It enumerates 20 parameters with 3-part differentiation of WBC.

Biochemical parameters: These parameters were measured using Prestige 24i- Automated Clinical Analyzer. (Cosmos Biomedical Ltd, Tokyo, Japan). The Prestige 24i has ion selective modules which additionally measure the concentration of the electrolytes, sodium, potassium and chloride in samples using indirect pontentiometry. The entire work was printed using Mixer 440 (Boule) / Xerox, which also has a compartment for mixing samples. The procedures were followed as contained in the standard operating manual.

Results: The evaluation of the effect of blood storage on both hematological and biochemical parameters was carried out using Citrate Phosphate Dextrose Adenine (CPDA -1) anticoagulated blood drawn from ten healthy volunteer donors and placed on the quarantine

\begin{tabular}{|c|c|c|c|c|c|c|c|c|}
\hline \multirow[t]{2}{*}{ Parameters } & \multicolumn{5}{|c|}{ Days } & \multirow[t]{2}{*}{ Total } & \multirow[t]{2}{*}{ F value } & \multirow[t]{2}{*}{$P$ value } \\
\hline & 1 & 7 & 14 & 21 & 28 & & & \\
\hline WBC $\times 10^{9} / \mathrm{L}$ & 5.43 & 4.37 & $3.49^{*}$ & $2.63^{*}$ & 2.77 & 3.73 & 7.142 & $0.000^{* * *}$ \\
\hline LYM $\times 10^{9} / \mathrm{L}$ & 3.08 & 3.47 & 2.97 & 2.25 & 2.32 & 2.81 & 2.557 & $0.051^{*}$ \\
\hline LYM \% & 57.18 & 75.77 & 86.72 & 87.82 & 85.06 & 78.51 & 10.641 & $0.000^{* * *}$ \\
\hline GRAN $10^{9} / \mathrm{L}$ & 1.93 & $0.33^{*}$ & $0.14^{*}$ & 0.09 & 0.13 & 0.52 & 52.431 & $0.000^{* * *}$ \\
\hline GRAN \% & 35.72 & $7.58^{*}$ & 5.09 & $4.93^{*}$ & 5.97 & 11.85 & 88.547 & $0.000^{* * *}$ \\
\hline MID 10\%/L & 0.42 & 0.57 & 0.38 & 0.29 & 0.32 & 0.39 & 1.977 & $0.114 \mathrm{~ns}$ \\
\hline MID \% & 7.18 & 10.65 & 8.19 & 7.25 & 8.97 & 8.44 & 1.083 & $0.376 \mathrm{~ns}$ \\
\hline $\operatorname{RBC} 10^{12} / \mathrm{L}$ & 4.07 & 4.16 & 8.19 & 7.25 & 8.97 & 8.44 & 1.083 & $0.376 \mathrm{~ns}$ \\
\hline HGB 9/dl & 11.85 & 12.13 & 11.82 & 12.11 & 12.14 & 4.13 & 0.171 & $0.952 \mathrm{~ns}$ \\
\hline HCT \% & 33.63 & 39.75 & 33.72 & 34.32 & 34.20 & 35.12 & 1.229 & $0.312 \mathrm{~ns}$ \\
\hline MCV F1 & 77.68 & 83.55 & 77.72 & 77.10 & 82.18 & 79.64 & 0.583 & $0.677 \mathrm{~ns}$ \\
\hline $\mathrm{MCHC}$ g/dl & 35.26 & 35.00 & 35.22 & 35.37 & 35.59 & 35.28 & 0.904 & $0.470 \mathrm{~ns}$ \\
\hline $\mathrm{MCH}$ pg & 29.18 & 28.46 & 29.14 & 29.02 & 29.23 & 29.00 & 0.403 & $0.805 \mathrm{~ns}$ \\
\hline RDW \% & 13.33 & 14.46 & 14.56 & 15.16 & 15.04 & 14.51 & 6.101 & $0.001^{* * *}$ \\
\hline RDWA FL & 64.41 & 67.11 & 67.85 & 66.66 & 69.14 & 67.03 & 1.218 & $0.316 \mathrm{~ns}$ \\
\hline PLT 104/L & 112.70 & 113.50 & 110.10 & 88.57 & 105.20 & 106.01 & 1.584 & $0.195 \mathrm{~ns}$ \\
\hline MPV FL & 7.75 & 8.22 & $8.34^{*}$ & 8.48 & 8.92 & 8.34 & 6.27 & $0.000^{* \star *}$ \\
\hline PDW FL & 10.41 & 10.97 & 11.16 & 11.47 & 12.13 & 11.22 & 5.521 & $0.001^{* * *}$ \\
\hline PCT \% & 0.08 & 0.08 & 0.08 & 1.28 & 0.09 & 0.32 & 2.235 & $0.080 \mathrm{~ns}$ \\
\hline LPCR \% & 16.03 & 18.44 & 19.43 & 9.23 & 22.20 & 11.06 & 1.706 & $0.165 \mathrm{~ns}$ \\
\hline ESR mm/h & 2.90 & $6.60^{*}$ & 5.60 & 2.80 & 2.50 & 4.08 & 3.714 & $0.011^{* *}$ \\
\hline$=$ & \multicolumn{8}{|c|}{ Significant at $P<0.05$} \\
\hline ** & \multicolumn{8}{|c|}{ Significant at $P<0.01$} \\
\hline$* * *$ & \multicolumn{8}{|c|}{ Significant at $P<0.001$} \\
\hline ns & Not sign & & & & & & & \\
\hline
\end{tabular}

Table 1: Mean test of significance for all the days (haematological parameters). 


\begin{tabular}{|l|l|l|l|l|l|l|l|l|}
\hline \multirow{2}{*}{ Parameters } & \multicolumn{5}{|c|}{ Days } & Total & $\begin{array}{l}\text { F } \\
\text { value }\end{array}$ & P value \\
\cline { 2 - 10 } & $\mathbf{1}$ & $\mathbf{7}$ & $\mathbf{1 4}$ & $\mathbf{2 1}$ & $\mathbf{2 8}$ & & \\
\hline $\begin{array}{l}\text { Total Protein } \\
\text { g/L }\end{array}$ & 62.60 & 58.40 & 62.80 & 57.60 & 61.0 & $60.48^{*}$ & 1.394 & $0.251^{\text {ns }}$ \\
\hline ALB. g/L & 36.70 & 35.80 & 34.80 & $33.20^{*}$ & 32.60 & 34.62 & 2.980 & $0.029^{*}$ \\
\hline Na mEq/L & 137.38 & 135.30 & $118.94^{*}$ & 129.33 & 126.25 & 129.44 & 1.938 & $0.121^{\text {ns }}$ \\
\hline K mEq/L & 2.64 & 6.14 & 9.25 & 11.31 & 15.71 & 9.01 & 15.145 & $0.000^{\text {*** }}$ \\
\hline C1 mEq/L & 75.93 & 73.37 & 69.78 & 72.05 & 69.82 & 72.19 & 1.817 & $0.142^{\text {ns }}$ \\
\hline
\end{tabular}

$\begin{array}{lll}* & = & \text { Significant at } P<0.05 \\ * * * & = & \text { Significant at } P<0.001\end{array}$

$\begin{array}{lll}* * * & = & \text { Significant at } P \\ \text { ns } & = & \text { Not significant }\end{array}$

Table 2: Mean test of significance for all the days (Biochemical parameters).

shelf of the blood bank refrigerator. The blood was kept for 28 days and samples were evaluated on days 1, 7, 14, 21 and 28 .

\section{Mean values of hematological and biochemical parameters}

At the end of the study period as shown in (Table 1 ), the mean values of some hematological parameters were as follows: WBC $\left(3.73 \times 10^{9} / \mathrm{L}\right)$, Hgb (12.01 g/dl), PCV (35.12\%), Lymphocytes $\left(2.81 \times 10^{9} / \mathrm{L}\right)$, Granulocytes $\left(0.52 \times 10^{9} / \mathrm{L}\right), \mathrm{MCHC}(35.28 \mathrm{~g} / \mathrm{dl}), \mathrm{MCV}(35.28 \mathrm{fl}), \mathrm{MCH}(14.51$ $\mathrm{pg})$, Platelet $\left(106.01 \times 10^{9} / \mathrm{l}\right.$, ESR $(4.08 \mathrm{~mm} / \mathrm{hr})$. The mean biochemical parameters (Table 2) were obtained as follows: Total protein $(60.48$ $\mathrm{g} / \mathrm{L})$, Albumin $(34.62 \mathrm{~g} / \mathrm{L}), \mathrm{Na}(129.44 \mathrm{mEq} / \mathrm{L}), \mathrm{K}(9.01 \mathrm{mEq} / \mathrm{L}), \mathrm{Cl}$ $(72.19 \mathrm{mEq} / \mathrm{L})$. Analysis of variance showed that at the end of the study period, significant differences were noted in 9 out of the 21 parameters evaluated, as shown in (Table 1) WBC $(\mathrm{F}=7.142, \mathrm{P}<0.05)$, Differential lymphocytes $(\mathrm{F}=10.641, \mathrm{P}<\mathrm{P}>0.0001)$, absolute and differential granulocytes $(\mathrm{F}=52.431, \mathrm{P}<0.0001$ and $\mathrm{F}=88.547, \mathrm{P}<0.0001)$, $\mathrm{MPV}(\mathrm{F}=6.27$, $\mathrm{P}<0.0001)$, PDW $(\mathrm{F}=5.521, \mathrm{P}<0.0001)$ and $\mathrm{ESR}(\mathrm{F}=3.714, \mathrm{P}<0.0001)$. As shown in (Table 2), there was a significant effect of storage on two out of five parameters studied. Albumin $(\mathrm{F}=2.980 \mathrm{P}<0.02)$ and potassium $(\mathrm{F}=15.145, \mathrm{P}<0.001)$ storage was not found to exert any influence on other parameters. There was a significant decrease in albumin concentration and steady increase in potassium values.

\section{Discussion}

There is substantial evidence from in vitro studies documenting the change that hematological parameters undergo during storage. When changes observed in the hematological parameters were categorized based on whether the initial days mean values were maintained when compared with other days, (below the lowest normal value), normal (within the normal range), or high (above the highest normal value), some of the hematological parameters analyzed decreased or increased. MPV and LPCR showed drastic increase from day 14 down to day 28. This agrees with the work done by Cohl et al. [12], who using Coulter Gen. S. on $40 \mathrm{~K}_{3}$ (Tripotassium ethylenediamine tetra acetate) EDTAanticoagulated blood specimen, found that MPV initially increased steadily, reaching a maximum mean percent change on day 5 , and on day 6 and 7, the mean percentage change had drastically increased. The collection, processing and storage of platelets for clinical use have undergone significant changes over the last few decades and novel approaches are being investigated to develop improved platelets products on new anticoagulant and additive solutions, modified storage containers and collection sets, procedures for virus and bacterial inactivation, chemical and physical methods to maintain the shelf life in development of artificial or pseudo artificial platelet products [12].

When the mean values of WBC on day 1 was compared to day 7 , it was observed that there was rapid deterioration in granulates WBC. These changes in white blood cells are most likely due to the

sum effects of the loss of individual cell characteristics specifically degeneration that is known to occur as the cell ages [12]. Clinical implications collectively known as the RBC storage lesion, is in part related to bioreactive substances released by leucocytes in the storage medium, such as histamine, lipids, and cytokines, which may exert direct effects on recipients, but many others are related to metabolic activity with the senescence, such as membrane vesiculation, decrease in cell size, increase of cell density, alteration of cytoskeleton, enzymatic desilylation and phosphatidylserine exposure [4].

A progressive increase in RDW was noticed in this study, after comparison of the mean cell value of day 1 and 14 and this agrees with the study of Cohl et al. [12]. Other hematological parameters remained fairly stable during this study period, hence may be considered acceptable for clinical utility.

In this study, potassium increased within the period of 7 days and continued subsequently. The only important electrolyte change in stored blood is that of potassium. During blood storage there is a slow but constant leakage of potassium from cells into surrounding plasma. In severe kidney disease even small amount of potassium fluctuations can be dangerous and relatively fresh or washed red cells are indicated. Potassium loss is recognized to be secondary to the changes in metabolic activity with cooling. The loss of DPG and reduced glycolytic activity are also related to decreasing $\mathrm{pH}$ [4]. The leakage of potassium from cells into surrounding plasma may be responsible for the drastic progression in potassium increase in this study. Sodium on the contrary reduced, suggesting that sodium in stored whole blood may produce adverse effect after transfusion. The increase in potassium value and reduction in sodium value simply indicates the preference of component therapy to whole blood transfusion.

The results reported herein have significant implications for blood transfusion managers, persons who work at the transfusion centres, public health officials, and clinicians, and suggest an urgent need for the introduction of policies for safe transfusion practices and education among blood donors and staff members at the centers. This is necessary because the demand for blood in BMSH is high as a result of excessive incidence of infections that cause anemia, malnutrition, surgical emergencies including road traffic accidents, and obstetrical emergencies associated with blood loss.

\section{Conclusion}

Rapid degeneration of leukocytes could lead to immunodulation related to blood transfusion. Whole blood should be leukodepleted before storage if it must be used beyond one week.

\section{References}

1. Koch CG, Li L, Sessler DI, Figueroa P, Hoeltge GA, et al. (2008) Duration of red-cell storage and complications after cardiac surgery. $\mathrm{N}$ Engl J Med 358 : 1229-1239.

2. Bonaventura J (2007) Clinical implications of the loss of vasoactive nitric oxide during red blood cell storage. Proc Natl Acad Sci U S A 104: 19165-19166.

3. Bennett-Guerrero E, Veldman TH, Doctor A, Telen MJ, Ortel TL, et al. (2007) Evolution of adverse changes in stored RBCs. PNAS 104: 7063-7068.

4. Hess JR (2006) An update on solutions for red cell storage. Vox Sanguinis 91:13-19.

5. Bruce-Chwatt LJ (1972) Blood transfusion and tropical disease. Tropical Diseases Bulletin 69: 825-862.

6. Thon IN, Schubert P, Duguay M, Serrano K, Lin S, et al. (2008) Comprehensive 
Citation: Adias TC, Moore-lgwe B, Jeremiah ZA (2012) Storage Related Haematological and Biochemical Changes of CPDA-1 Whole Blood in a Resource Limited Setting. J Blood Disorders Transf 3:124. doi:10.4172/2155-9864.1000124

Page 4 of 4

proteomic analysis of protein changing during platelet storage requires complementary proteomic approaches. Transfusion 48: 425-435.

7. Ono T, Kitaguchi K, Takehara M, Shiliba M, Hayami K (1981) Serum-constituents analyses: effect of duration and temperature of storage of clotted blood. Clinica chemistry $27: 35-38$.

8. Hankinson SE, London SJ, Chute CG, Barbieri R L, Jones L, et al. (1989) Effect of transport conditions on the stability of biochemical markers in blood. Clinical Chemistry 35: 2313-2316.

9. Heins M, Heil W, Withold W (1995) Storage of serum or whole blood samples?
Effects of time and temperature on 22 serum analytes. Eur J Clin Chem Clin Biochem 33: 231-238.

10. Shields CE (1969) Effects of adenine on stored erythrocytes evaluated by autologous and homologous transfusion. Transfusion 9: 115-119.

11. Monica C (2000) District Laboratory Practice in Tropical countries, part 2 Cambridge University Press, Great Britain. 348-361.

12. Cohl SD, Saleem A, Makkaoui DE (1981) Effects of storage of blood on stability of hematologic parameters. Am J Clin Pathol 76: 67-69. 